\title{
MOIETIES AND MORTUARY MOUNDS: DUALISM AT A MOUND AND ENCLOSURE COMPLEX IN THE SOUTHERN BRAZILIAN HIGHLANDS
}

\author{
Mark Robinson, José Iriarte, Jonas Gregorio De Souza, Rafael Corteletti, Priscilla Ulguim, \\ Michael Fradley, Macarena Cárdenas, Paulo De Blasis, Francis Mayle, and Deisi Scunderlick
}

\begin{abstract}
Excavations at Abreu Garcia provide a detailed case study of a mound and enclosure mortuary complex used by the southern proto-Jê in the southern Brazilian highlands. The recovery of 16 secondary cremation deposits within a single mound allows an in-depth discussion of spatial aspects of mortuary practices. A spatial division in the placement of the interments adds another level of duality to the mortuary landscape, which comprises: (1) paired mound and enclosures, (2) twin mounds within a mound and enclosure, and (3) the dual division in the mound interior. The multiple levels of nested asymmetric dualism evoke similarities to the moiety system that characterizes modern southern Jê groups, highlighting both the opposition and the complementarity of the social system. The findings offer deeper insight into fundamental aspects of southern proto-Jê social organization, including the dual nature of the community, the manifestation of social structure in the landscape, and its incorporation into mortuary ritual. The results have implications for research design and developing appropriate methodologies to answer culture-specific questions. Furthermore, the parallels among archaeology, ethnohistory, and ethnography enable an understanding of the foundation of modern descendent groups and an assessment of the continuity in indigenous culture beyond European contact.
\end{abstract}

As escavações no sítio Abreu Garcia oferecem um estudo de caso detalhado de um conjunto de recintos e montículos funerários utilizado pelos grupos proto-Jê meridionais nas terras altas do sul do Brasil. A descoberta de dezesseis depósitos cremados secundários dentro de um único montículo permite uma discussão profunda da dos aspectos espaciais das práticas mortuárias. Uma divisão espacial na disposição dos enterramentos acrescenta outro nível de dualidade à paisagem mortuária, que compreende: (1) recintos e montículos dispostos em pares, (2) montículos duplos no interior de um único recinto, e (3) a divisão dual no interior do montículo. Os múltiplos níveis de dualismo assimétrico evocam similaridades com o sistema de metades que caracteriza os grupos Jê meridionais modernos, ressaltando tanto a oposição quanto a complementaridade no sistema social. As descobertas propiciam uma compreensão mais profunda dos aspectos fundamentais da organização social proto-Jê meridional, incluindo a natureza dual da comunidade, as manifestações da estrutura social na paisagem e a sua incorporação no rito mortuário. Os resultados têm implicações para o planejamento das pesquisas e desenvolvimento de metodologias apropriadas para responder questões culturais específicas. Além disso, os paralelos entre arqueologia, etno-história e etnografia permitem uma compreensão da fundação dos grupos descendentes modernos e uma avaliação da continuidade das culturas indígenaspara além do momento de contato com os europeus.

\footnotetext{
Mark Robinson, José Iriarte, and Jonas Gregorio De Souza — Department of Archaeology, University of Exeter, Devon, EX4 4QE, UK (markrobinson.uk@gmail.com)

Rafael Corteletti $\boldsymbol{~ - ~ I n s t i t u t o ~ d e ~ C i e ̂ n c i a s ~ H u m a n a s , ~ D e p a r t a m e n t o ~ d e ~ A n t r o p o l o g i a ~ e ~ A r q u e o l o g i a , ~ U n i v e r s i d a d e ~ F e d e r a l ~ d e ~}$ Pelotas, RuaCel. Alberto Rosa, 154, RS, Brazil

Priscilla Ulguim $\square$ School of Science and Engineering, Teeside University, Middlesbrough, Tees Valley, TS1 3BX, UK Michael Fradley $\square$ School of Archaeology, University of Oxford, Hayes House, 75 George Street, 1st Floor, Oxford, OX1 2BQ, UK

Macarena Cárdenas and Francis Mayle — Centre for Past Climate Change and Department of Geography \& Environmental Science, University of Reading, Berkshire, RG6 6DW, UK

Paulo De Blasis $\square$ Laboratório de Arqueologia Regional, Museu de Arqueologia e Etnologia, Universidade de São Paulo, Brazil

Deisi Scunderlick - Universidade do Sul de Santa Caterina, Av. José Acácio Moreira 787, Bairro Dehon, 88704-900, Tubarão, SC, Brazil
}

Latin American Antiquity 28(2), 2017, pp. 232-251

Copyright (C) 2017 by the Society for American Archaeology doi:10.1017/laq.2017.11 
$\mathrm{T}$ he dead offer a window into the history of the individual and the community because of the encoding of fundamental social institutions into mortuary practices. The patterns and variability of mortuary treatments reflect the socioreligious beliefs of a community, which delineate conceptions of the dead. But they may also reflect the social identity of an individual as defined by the form and organization of social systems (Binford 1971; Dillehay 1995; O’Shea 1984; Pearson 1999; Tainter 1978; Tarlow and Stutz 2013).

In southern Brazil, modern southern Jê groups are characterized by a social organization revolving around dual, exogamous, asymmetrical, patrilineal moieties. All people, objects, and natural phenomena are divided between the two moieties as dual oppositions. Public events overtly emphasize moiety membership through visual symbols and the performance of specific tasks. Funerary ritual, in particular, reflects this system, with burials conscripted as communitywide integrative events that reinforce social hierarchy, the dual organization of the group, and the individual's social identity (Baldus 1937; Crépeau 1994; Métraux 1946; Nimuendajú 1993 [1913]; Veiga 2006).

Although we need to be aware of the potential differences between the earlier archaeological contexts and those reported during the seventeenth through twentieth centuries, especially in the face of European colonization of the region, there are general ideological and structural arrangements that appear to be constant over time. As the work of Iriarte and coauthors (2013) has shown, it is possible to interpret the highly structured archaeological patterns of southern proto-Jê mound and enclosure complexes (hereafter MECs) through reasoned analogies from the ethnohistorical and ethnographic record, drawing on the historical continuity that exists in the organization of ritual space. In particular, records of highly structured, spatially defined ritual activity in the funerary landscape and ethnographically documented use of mounds for the interment of the deceased by modern southern Jê groups provide a rich source of analogical information.

The southern proto-Jê employed MECs as funerary monuments to bury the cremated remains of select members of the community circa A.D. 1000-1700. Recent excavations at Abreu Garcia, an MEC near Campo Belo do Sul, Santa Catarina state, in use from the midfifteenth century to the late seventeenth (Table 1; Figure 1), suggest that dual social organization was well established and an integral feature of the funerary landscape, manifesting across multiple spatial levels of (1) a paired MEC, (2) twin mounds within an MEC, and (3) the internal division of the mounds.

The following section provides a brief synthesis of southern Jê dualism and funerary rites, which serves as a point of departure for our interpretations. This is followed by an overview of the archaeology of mortuary structures in the southern Brazilian highlands and an examination of excavations at Abreu Garcia. We conclude with a discussion of features of cremation deposits and the dualism in site plan, materials, and internal mound space in light of the new data from Abreu Garcia.

\section{Modern Jê Organization and Mortuary Practice}

The prevalence of dual social organization has been documented ethnographically throughout South America, with an increasing number of examples from archaeological contexts (Hornborg 1988; Lévi-Strauss 1944; Moore 1995; Nimuendajú and Lowie 1937; Turner 1996; Zuidema 1964). That the moiety system is ancient among the southern branch of the Jê family is attested by the fact that it is found in virtually all northern Jê societies in central Brazil and among some of their Macro-Jê neighbors (Maybury-Lewis 1979). The Jê linguistic family was first recognized in the nineteenth century (Martius 1867). Together with a number of smaller families, it is now considered part of a broader Macro-Jê stock, one of the largest of South America (Davis 1966, 1968; Ribeiro 2006; Rodrigues 1999). Notable members of the Macro-Jê stock include the Bororo, Kayapó, Xavante, and other central Brazilian peoples whose dual organization was a focus of anthropological studies in the 1960s (MayburyLewis 1979). Beyond the southern highlands, Jê speakers are distributed over a vast territory 
Table 1. Radiocarbon Dates from Abreu Garcia.

\begin{tabular}{lllccl}
\hline Context & Material & $\begin{array}{l}\text { Laboratory } \\
\text { Number }\end{array}$ & $\begin{array}{l}\text { Conventional } \\
\text { Radiocarbon Age B.P. }\end{array}$ & $\delta^{13}$ C \%o & Cal A.D. $(2 \sigma)^{\mathrm{a}}$ \\
\hline $\begin{array}{llll}\text { Cluster 6 } \\
\text { Cluster 16 }\end{array}$ & Charcoal & Beta 417389 & $390 \pm 30$ & -24.1 & $1459-1627$ \\
Cluster 14 & Charcoal & Beta 395744 & $370 \pm 30$ & -26.4 & $1465-1636$ \\
Cluster 12 & Charcoal & Beta 395742 & $400 \pm 30$ & -23.4 & $1454-1627$ \\
Cluster 11 & Charcoal & Beta 395740 & $230 \pm 30$ & -27.8 & $1645-1809$ \\
& Charcoal & Beta 395743 & $270 \pm 30$ & -25.7 & $1625-1679(p=0.53)$ \\
Burned Feature & Charcoal & Beta 414096 & $300 \pm 30$ & -23.3 & $1504-1560(p=0.39)$ \\
& & & & & $1616-1671(p=0.53)$ \\
Mound B, Burial 1 & Charcoal & Beta 395741 & $360 \pm 30$ & -24.9 & $1482-1642$ \\
Mound B, Burial 2 & Charcoal & UGAMS 19003 & $330 \pm 20$ & -24.5 & $1505-1650$ \\
\hline
\end{tabular}

${ }^{\mathrm{a}}$ Calibrations from OxCal v4.2.4 (Bronk Ramsey 2009). All calibrations based on SHCal 13 data set (Hogg et al. 2013).
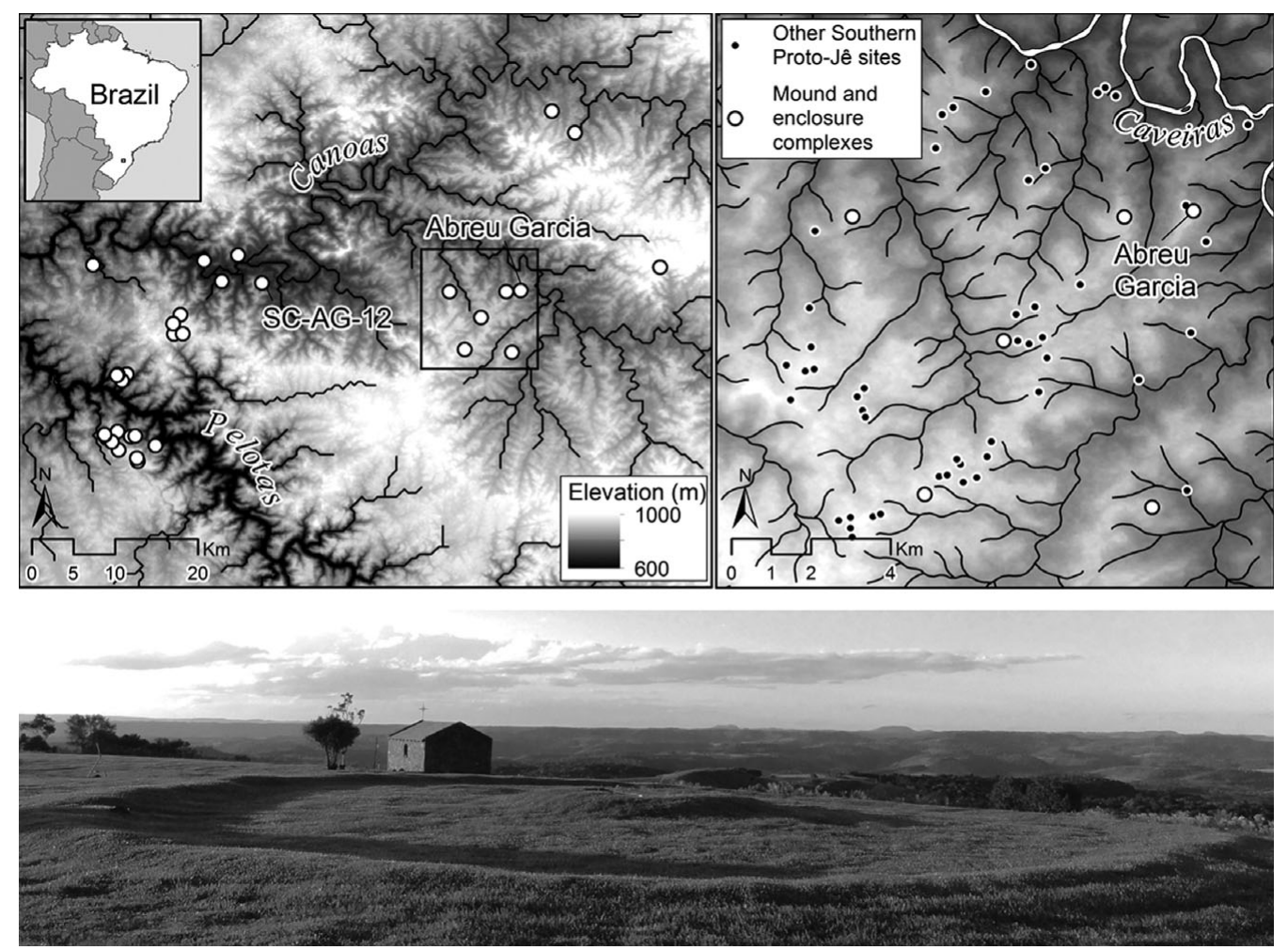

Figure 1. Map of Abreu Garcia and surrounding region, with photograph of MEC1 showing the modern chapel and the location of the complex at the edge of the plateau with commanding views.

of the central Brazilian cerrados (savannas), an area of high ethnolinguistic diversity where the homeland of this family is thought to lie. Glottochronological estimates place the initial split of the Jê languages around 3000 B.P., the southern branch being the first to diverge (Urban 1992). The two remaining modern southern Jê groups, the Kaingang and the Xokleng, also exhibit dual organization. The moiety system of the Kaingang is rooted in the lineages originating from two mythological twin brothers, Kamé and Kairu (Veiga 1994). In the Kaingang origin myth, after a cataclysmic flood, Kamé and Kairu independently created all beings of nature, setting the stage for a dually divided world in which everything is assigned to one brother or 
the other in an all-encompassing classificatory system (Borba 1908; Nimuendajú 1993 [1913]). Before the brothers ascended into the heavens as the Sun (Kamé) and Moon (Kairu), they dictated the order by which society should be structured, establishing the division into complementary moieties as well as the rules for moiety recruitment through patrilineal descent and exogamous marriage. The brothers lend their names and their associated traits to the two moieties. Kamé is associated with the Sun, west, day, thick body, high, persistence, and permanence, while Kairu is associated with east, Moon, night, slim body, low, impermanence, and transformation (Silva 2002). The mythology points toward a complementary but asymmetrical relationship, with the successes of Kamé contrasting with the imperfect and unfinished attempts of Kairu. Possessing stronger souls, members of the Kamé moiety can demand more lavish ritual and privileged locations, such as higher elevations (Crépeau 1994, 2002; Veiga 2006).

The Xokleng (more recently self-identified as the Laklãnõ) are divided into three exogamous patrilineal clans called Mê-vidn, Mê-calêbn, and Mê-kúi-ken. As Métraux (1946) showed, however, this system was originally dual, with the first clan (Mê-vidn) corresponding to the Kairu moiety of the Kaingang and the second clan (Mêkúi-ken) being equivalent to the Kamé moiety. The function of the third clan is predominantly ceremonial, and membership is not necessarily inherited (Silva 2001; Veiga 1994). Modern anthropological studies document a Xokleng culture that has undergone radical social transformation in the face of near ethnocide in the early twentieth century (e.g., Cruz Conceiçáo 2015; Henry 1964; Hoffman 2010; Santos 1973; Urban 1978, 1985; Wiik and Mota 2014). Dispossessed of their land, previously sedentary communities were forced into smaller, mobile groups (Henry 1964; Loch 2004; Noelli 2000), resulting in social, economic, subsistence, political, and ritual adaptation to a new way of life. Modern accounts of the Xokleng are therefore particularly problematic for analogical application to archaeological contexts (Noelli 2000), and as such this paper relies on data from the Kaingang.

Mortuary rituals associated with mound building by the southern Jê have been recorded in European accounts since the seventeenth century (Baldus 1937; Becker 1976; Crépeau 1994; Henry 1964; Maniser 1930; Métraux 1946; Nimuendajú 1993 [1913]; Paula 1924; Veiga 2000, 2006). The practice of interring in mounds continued into the twentieth century. Ceremonies at mounds were the most important ritual practices for the community and were public events that specifically emphasized the dual organization of the group (Baldus 1937; Crépeau 1994; Métraux 1946; Nimuendajú 1993 [1913]; Veiga 2006). Both halves have integral roles to play in the structure of public ceremony. Moiety affiliation is marked through body ornamentation: members of the Kamé moiety paint their bodies with black stripes, lines, and open shapes using burned pine chips (Araucaria angustifolia [Bertol.] Kuntze), whereas Kairu members paint red circles and closed shapes using Symplocos parvifolia (Da Silva 2011). During the Kaingang kiki funerary ritual, the ceremony in the cemetery adheres to an organized east-west spatial and conceptual division (Crépeau 1994; Veiga 2000). For example, two fires are lit, one in the east for Kairu, and one in the west for Kamé. The events also demonstrate the complementarity of the moiety system; each fire and the accompanying prayers may only be performed by members of the opposite moiety (Da Silva 2011; Veiga 2006).

\section{Archaeology of the Southern Proto-Jê}

Southern proto-Jê culture covered a vast area (more than $600 \mathrm{~km}$ north-south) encompassing diverse environments across the southern highlands and Atlantic forest of the modern Brazilian states of southern São Paulo, Paraná, Santa Catarina, and Rio Grande do Sul and Misiones province, Argentina. The highland plateau (700$1,850 \mathrm{~m}$ asl) is dominated by mixed Araucaria forest and high-altitude grasslands (Campos de Cima da Serra) (Klein 1975).

Ancestral to the modern speakers of the southern branch of the Jê language family, and sharing a broadly defined material culture known as the Taquara/Itararé Tradition, the southern proto-Jê are characterized by the use of diagnostic small, thin-walled ceramic vessels, pithouses, MECs, and rock art (e.g., Araújo 2007; Beber 2005; 
De Masi 2009; Iriarte et al. 2013; Noelli 2005; Riris and Corteletti 2015). The territorial extent of the Taquara/Itararé Tradition-covering most of the southern Brazilian highlands, adjacent escarpment, and parts of the Atlantic coastcoincides with the historical distribution of the Kaingang and Xokleng (Da Silva 2001; Jolkesky 2010; Noelli 2005). Beyond the spatial overlap, the dates of occupation of many Taquara/Itararé sites continue into the early colonial period, and there is continuity in material culture (ceramics), burial practices (earthen mounds), and decorative motifs in rock art and ceramics between the precolonial Taquara/Itararé Tradition and the historical Kaingang and Xokleng (Da Silva 2001). For those reasons, most archaeologists agree in attributing the Taquara/Itararé material culture to the ancestors of the extinct Kimdá and Ingáin groups and the direct ancestors of modern Kaingang and Xokleng (Jolkesky 2010). Following that reasoning, and to emphasize the continuity, in this paper we refer to the Taquara/Itararé groups as the southern proto-Jê. These communities practiced a mixed economy, which combined harvesting the Paraná pine nut (A. angustifolia), hunting, gathering, and fishing with the cultivation of domestic crops. From a pithouse context, recent microbotanical studies have documented the consumption of manioc (Manihot esculenta Crantz), beans (Phaseolus sp.), maize (Zea mays L.), and squash (Cucurbita sp.), implying a degree of sedentary farming (Corteletti et al. 2015).

The Taquara/Itararé Tradition began to spread after A.D. 1, reaching new levels of regional organization and political complexity around A.D. 1000 (Iriarte et al. 2013). The first major earthworks, in the form of domestic pithouses, begin to appear circa A.D. 400. Pithouses range in size from 2 to $20 \mathrm{~m}$ in diameter and range from solitary pits to clustered "villages" containing more than 100 structures. Around A.D. 1000, oversized pithouses and MECs begin to appear on the landscape (Copé 2006; Corteletti 2012; Iriarte et al. 2013; Schmitz et al. 2013). Interestingly, pollen records document an expansion of Araucaria forest coinciding with these innovations (Behling 1995, 1998; Bitencourt and Kraspenhar 2006; Iriarte and Behling 2007).

\section{Mound and Enclosure Complexes}

MECs are funerary monuments, occurring in isolation and in groups, concentrated along the Pelotas and Canoas river basins and typically occupying the most prominent hilltops with wide viewsheds (Corteletti 2012; Corteletti et al. 2015; De Masi 2009). Just over 50 MECs have been documented, although few have been excavated (Beber 2005; Chmyz 1968; Copé et al. 2002; Corteletti 2012; De Masi 2005; De Souza and Copé 2010; De Souza et al. 2016; Herberts and Müller 2007; Iriarte et al. 2008, 2010, 2013; Müller 2008; Naue et al. 1989; Reis 2007; Ribeiro and Ribeiro 1985; Rohr 1971; Schmitz et al. 2010). Published dates of MECs are limited, with the earliest dated to circa A.D. 1000 (Posto Fiscal and SC-AG-75) and an abundance of dates in the fifteenth through seventeenth centuries (see Iriarte et al. 2013; Iriarte et al. 2016).

The complexes are characterized by circular, elliptical, rectangular, and keyhole-shaped earthworks surrounding one or more earthen mounds. Both raised rings and ditches were used as the encircling earthworks. Raised rings are up to $1 \mathrm{~m}$ high, $6 \mathrm{~m}$ wide, and $10-180 \mathrm{~m}$ in diameter. Ditches are typically shallow and narrow. More complex features, including entry avenues and attached ringlets, such as those at $\mathrm{El}$ Dorado, Misiones, Argentina (Iriarte et al. 2008, 2010) and SC-CL-37 in Santa Catarina (Reis 2007), are occasionally present. The mounds themselves are predominantly circular, although there are rectangular examples (e.g., SC-AG-12; De Masi 2009). When a single mound is present, it occupies the center of the enclosure. Two mounds typically follow a dual architecture pattern of distinctly different sizes on a southwestto-northeast alignment, with the larger structure in a higher elevation to the northeast (see Iriarte et al. 2013). Iriarte et al. (2013) argue that such MECs demonstrate a high level of spatial organization, where paired complexes of distinctly different sizes represent a dual ranked social structure.

The mounds are funerary, containing single and multiple cremated burials. In a few instances, excavation has determined that a mound was erected on top of the cremation pyre (De Masi 2009; De Souza and Copé 2010), although in most instances the cremation was transported 
from an off-site funeral pyre (Copé and Saldanha 2002; De Masi 2009; De Souza and Copé 2010; Müller 2008; Müller and Mendonça de Souza 2011). The most common grave goods, when present, are small ceramic vessels (rim diameter no larger than $15 \mathrm{~cm}$ ), possibly representing food and drink offerings.

\section{Abreu Garcia Site and Excavations}

The Abreu Garcia site is located on an elongated basaltic plateau with commanding views across the surrounding landscape (Figure 1). The archaeological site is on the northwestern edge of the plateau, consisting of two MECs and a solitary pithouse (Figure 2). MEC1 is the larger of the two. It incorporates a primary central mound and a secondary small mound to the northwest, both within an enclosure. The $0.4 \mathrm{~m}$ high, circular enclosing earthwork is $50 \mathrm{~m}$ in diameter and $4 \mathrm{~m}$ wide. The central mound (Mound A) measures $10 \mathrm{~m}$ in diameter and $0.8 \mathrm{~m}$ in height. The smaller mound (Mound B), to the northwest, measures $4 \mathrm{~m}$ in diameter and $0.2 \mathrm{~m}$ in height. MEC2 is much smaller, consisting of a single mound within an enclosing ditch and a small bank measuring $10 \mathrm{~m}$ in diameter. There is a single central mound (Mound C), $0.4 \mathrm{~m}$ in height and $5 \mathrm{~m}$ in diameter. The pithouse, measuring $5 \mathrm{~m}$ in diameter, is located $200 \mathrm{~m}$ along the plateau to the north. Each structure is in alignment, positioned close to the edge of the plateau. A stone chapel is a recent addition to the landscape. No further structures have been found on the plateau.

In 2014 , a $2 \times 5 \mathrm{~m}$ unit running parallel to the plateau's edge was excavated on the northeastern half of Mound A of MEC1. The recovery of cremated deposits prompted a second excavation in 2015. Excavations were also undertaken in Mound B of MEC1 and Mound C of MEC2. Test pitting was carried out on the enclosure rings, the inter-mound areas, and the internal off-mound space. Osteological analysis of the cremated remains is in a preliminary stage. As such, this paper focuses on spatial aspects of the mortuary context. In-field observation of MNI (minimum number of individuals), age, and faunal inclusions shows variability across contexts that does not appear to reflect prescribed practices of the social system and therefore does not affect the interpretations presented here.

\section{MEC1-Mound A}

Excavation over the two seasons confirmed the presence of two construction phases (Figure 3). The mound was constructed on the original ground surface, $20-30 \mathrm{~cm}$ above bedrock. The initial mound construction, consisting of a largely sterile clay matrix (Munsell 5YR 3/4), was capped by a layer of degraded yellow basalt. Our excavations have encountered similar basalt caps defining construction phases in both mound and pithouse architecture in the Campo Belo region. A second construction phase expanded the mound with the addition of a coarser red sandy clay matrix from a distinctly different source (Munsell 2.5YR 3/6).

Sixteen secondary cremation deposits were encountered across the two years of excavations in MEC1, with a spatial separation between the northeastern and southwestern halves paralleling the direction of the edge of the plateau (Figure 4). Nine cremation deposits (Clusters 1-9) were recovered in the southwest and seven (Clusters 10-16) in the northeast. The segregation is highlighted by the absence of deposits along the central axis and by a distinct difference between the two sides in burial contexts, with those in the southwest subject to more formal interment. The basalt cap also remains largely intact along the central axis, but is broken or absent above all cremation deposits except Cluster 16. The broken cap suggests these 15 deposits were later additions made by reentering the mound after the construction of the cap, with Cluster 16 potentially representing an early (or initial) burial as part of the original mound construction.

The seven cremation deposits in the northeastern half are located throughout the body of the mound below the level of the basalt cap. The interments include both well-defined and scattered deposits. Bioturbation alone does not appear to account for the difference in the concentration of the deposits because it is limited, with major root disturbance primarily located above the basalt cap. The more scattered cremation deposits do not show clear evidence of dispersal from an original concentration, with 


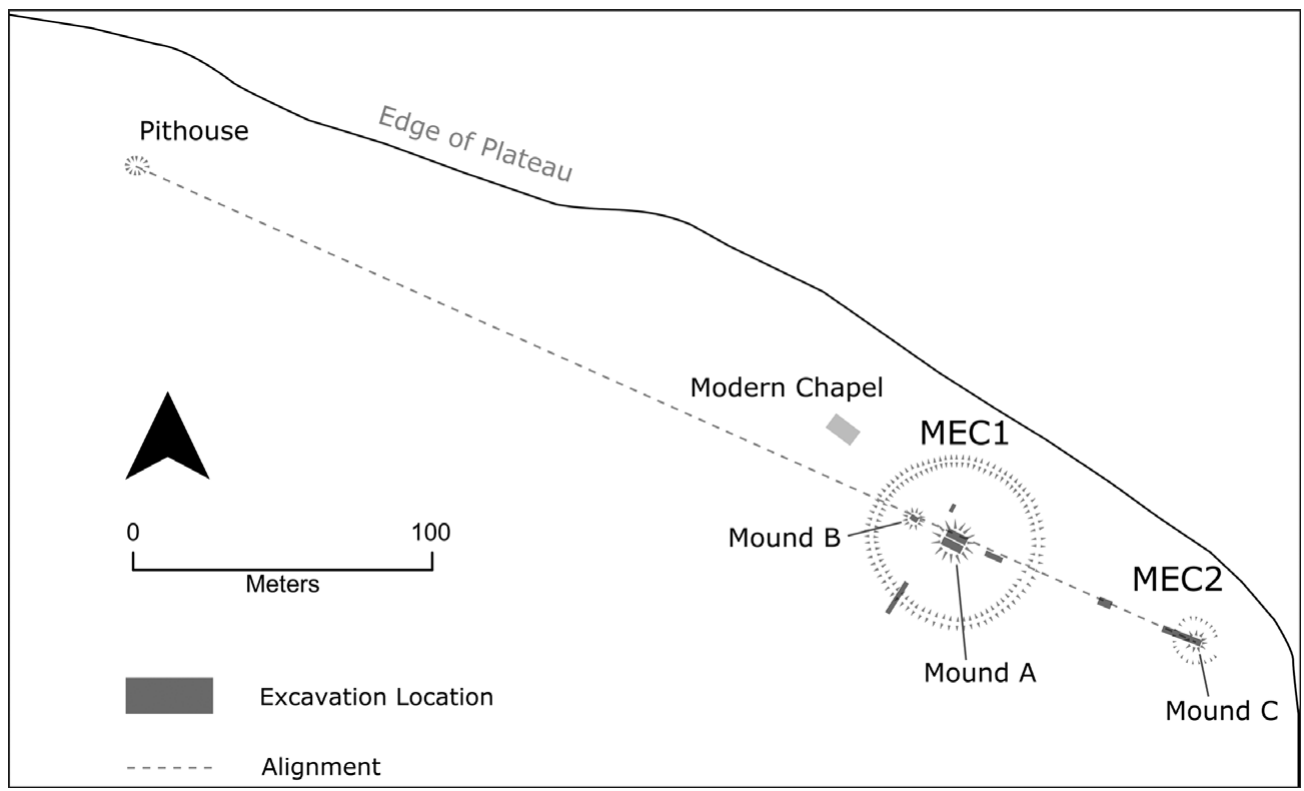

Figure 2. Map of the Abreu Garcia complex and excavation locations. The dashed line highlights the linear alignment of the structures.

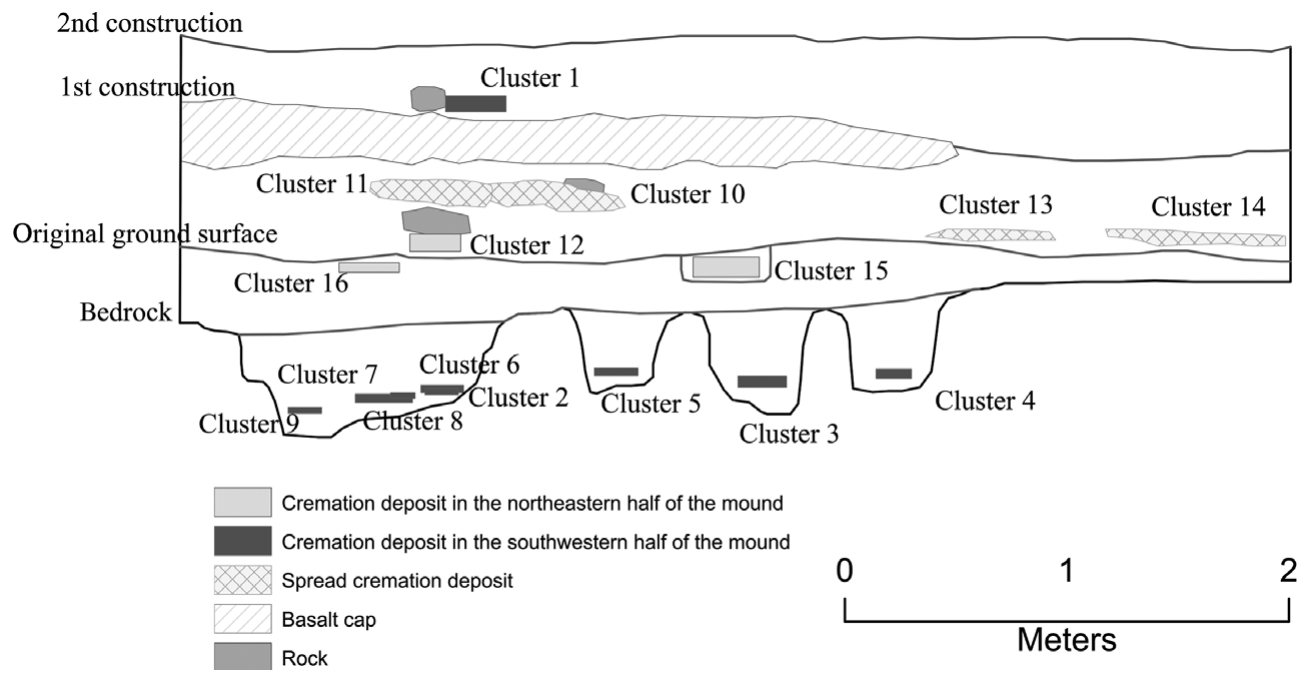

Figure 3. Amalgamated profile of Mound A showing construction phases and the location of cremation deposits.

the material from the deposits evenly spread, and the surrounding matrix shows no evidence of disturbance that would cause the spread. Three of the deposits, Clusters 12, 15, and 16, were well defined. A rectangular basalt stone covered Cluster 12 (230 \pm 30 B.P.), likely functioning as grave architecture. Cluster 16 (370 \pm 30 B.P.; Figure 5a) was placed directly on top of the bedrock and is one of only two deposits to include human teeth (the other being Cluster 1). Cluster 15, a concentrated deposit in the lower stratum (Figure 5b), contained charred seeds and several pieces of burned bamboo alongside more typical wood charcoal. Clusters 13 and 14, toward the northern corner of the excavation (Cluster 14, $400 \pm 30$ B.P.; Figure 5c), and Clusters 10 (Figure 5d) and 11 (Cluster 11, $270 \pm 30$ B.P.), in the east, lacked a demarcated shape 


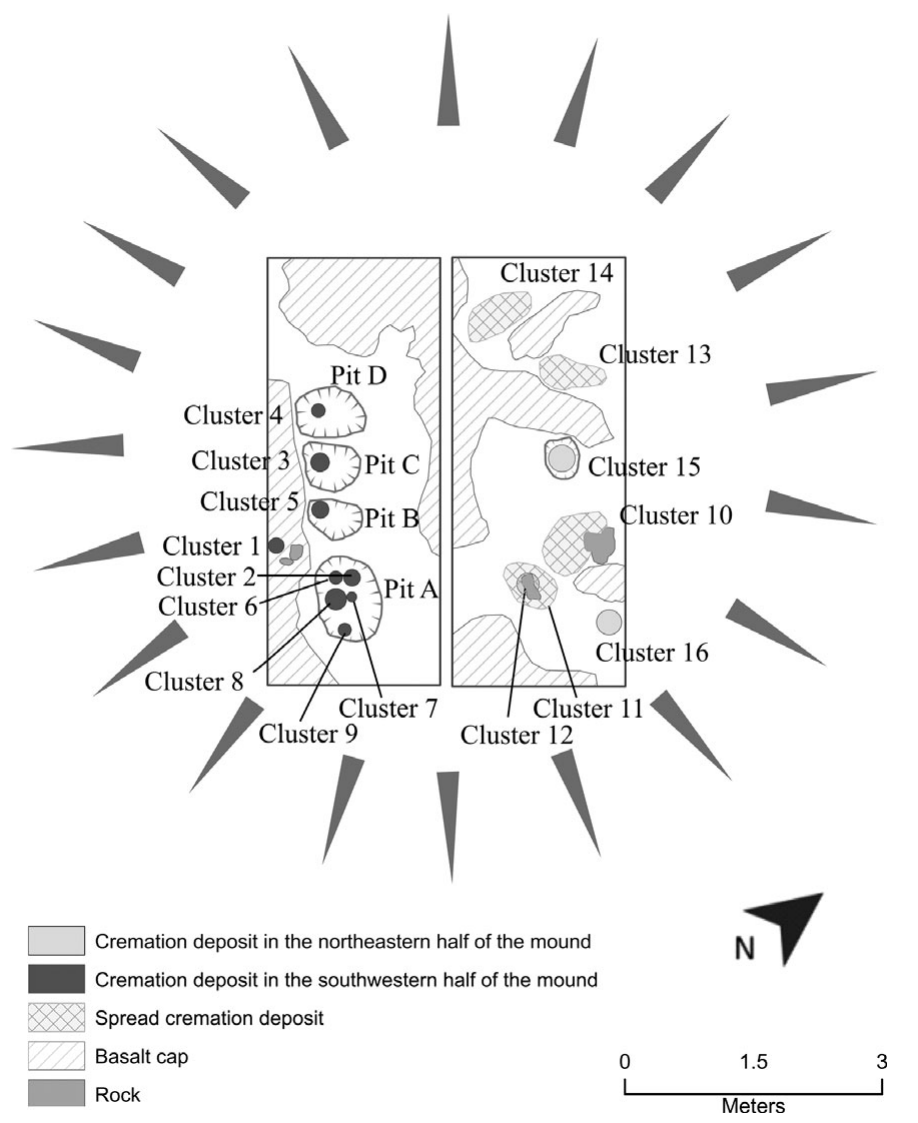

Figure 4. Plan view of cremated deposits and basalt cap. Note the intact basalt cap and absence of cremation deposits along the central axis.

or a distinctive core, suggesting that they were more scattered during interment. A concentration of pebbles immediately to the east of Cluster 10 may have served as grave architecture or offerings.

In comparison to the interments of the northeast, the nine cremation deposits in the southwestern half are spatially distinct and decidedly more formal. Eight of the deposits are located in four bedrock cut pits, while the ninth is placed above the basalt cap associated with stone grave architecture. The four pits are in a linear arrangement (Figure 6a), paralleling the edge of the plateau to the northeast and emphasizing the internal mound division. The basalt layer above the pits was fragmentary, suggesting that some, if not all, of the pits were entered after the second construction phase of the mound. Pits B, C, and D all contained single cremated deposits, whereas five separate cremated contexts were placed in
Pit A (Figure 6b) alongside a single complete incised ceramic vessel.

Overlapping material between all contexts in Pit A (Clusters 2, 6, 7, 8, and 9) suggests that the five deposits are from a single interment event and the pit was sealed with a cap that prevented sediment penetration, allowing time for the cremation containers to disintegrate and the contained material to spread. The ceramic vessel, a thin-walled cup with zigzag incised decoration (Figure 6c), appears to have been deposited as a separate event sometime after the interment of the cremation deposits. The vessel sits on $2 \mathrm{~cm}$ of sediment buildup above the collapsed spread of Cluster 9 and the edge of the spill from Cluster 7 , implying that enough time had passed for the cremation containers to disintegrate before the ceramic was deposited. Each of the five cremated deposits in Pit A showed distinct characteristics, enabling separation of the contexts. The red 

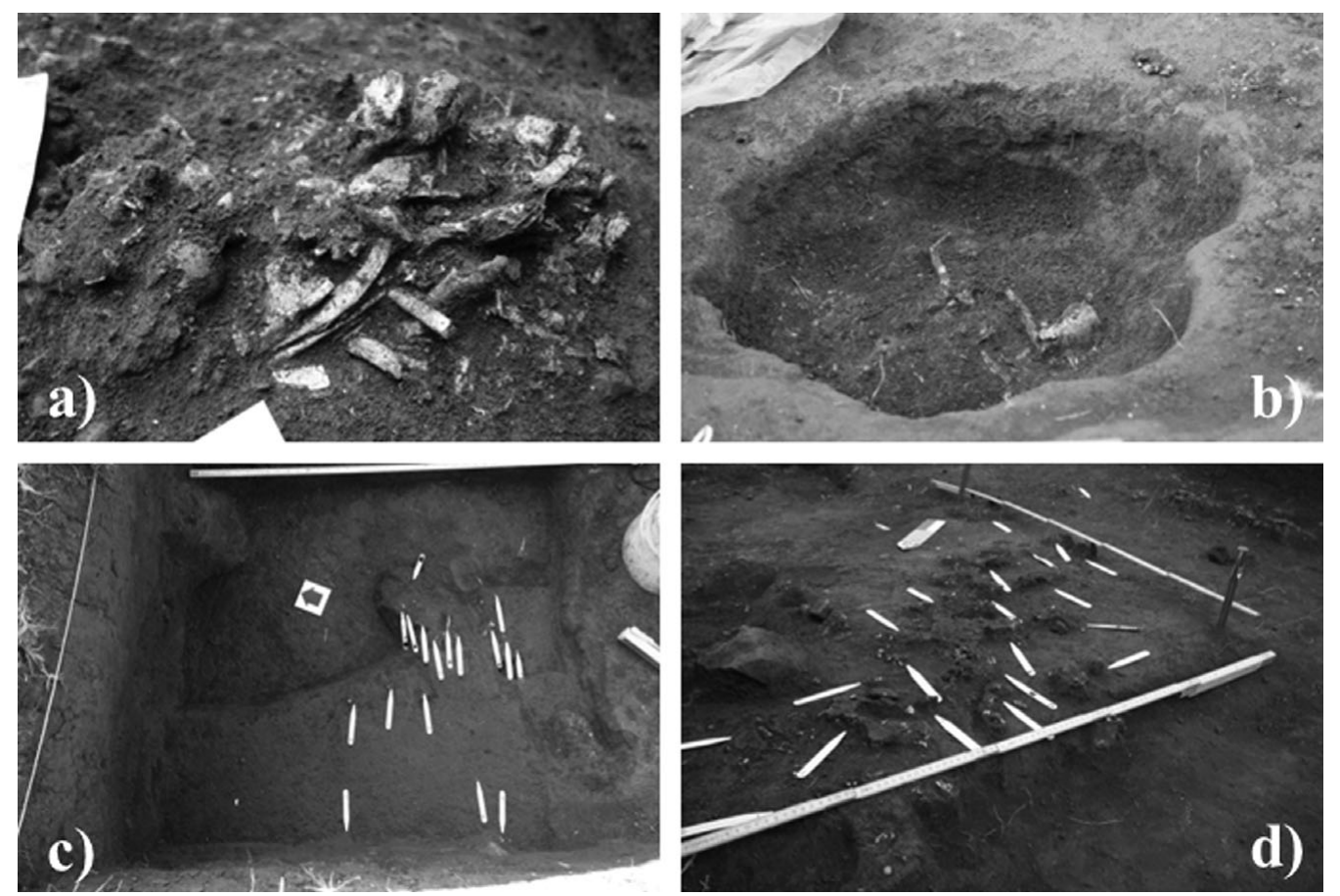

Figure 5. Cremated deposits in the northeastern half of Mound A: a) Cluster 16, b) Cluster 15 in well-defined cut, c) dispersed material of Cluster 14, d) dispersed material of Cluster 10.

color on the bones and the surrounding matrix and absence of charcoal distinguished Cluster 7 , suggesting that the bones were treated with ochre after collection from the cremation pyre.

Pits B, C, and D each contained a single cremation deposit, Clusters 5, 4, and 3, respectively. Field observations suggest that faunal (including bird) bone is present alongside human skeletal material in Cluster 5, and both adult and subadult bones are present in Cluster 3. Sixteen large ceramic fragments were encountered above Pit B. Many of the fragments refit and all are likely from a single vessel that is similar in form to the cup found in Pit A, albeit without decoration. A constructed wall separates Pit $\mathrm{C}$ from Pit D (Figure 6d), with skeletal material from Pit C spread beneath the wall. As such, the wall postdates the interment of Cluster 4 and is most likely a feature that was added at the same time as Cluster 3 to maintain spatial separation after Pit $\mathrm{C}$ was cut.

Just as the bedrock cut pits mark an interment choice distinct from the choices marked by the cremation deposits in the main body of the mound in the northeast, Cluster 1 also differs from the other locations as the only interment placed above the basalt cap. Cluster 1 also contains formal stone architecture (Figure 7). Clusters 1 and 16 are the only contexts that include dentition.

A deposit of charcoal was present in the southern half of the excavation unit. The deposit was fully contained within the excavation unit and does not continue into any profile. No human skeletal material was associated with the feature. Preliminary analysis of the charcoal identifies the presence of multiple wood species, confirming that the deposit was not a single tree or post. AMS dating of charcoal from the context provided a date of $300 \pm 30$ B.P. (Table 1). The late date and absence of the basalt cap above the feature confirm it was added after the second construction phase. The nature of the deposit remains ambiguous, possibly representing a self-contained firebased ceremony or a ritual attached to one of the pit interments. Current dates and stratigraphy do not allow direct association between the burned feature and an interment.

Including the complete vessel in Pit A and the fragments of the vessel above Pit B (counted 

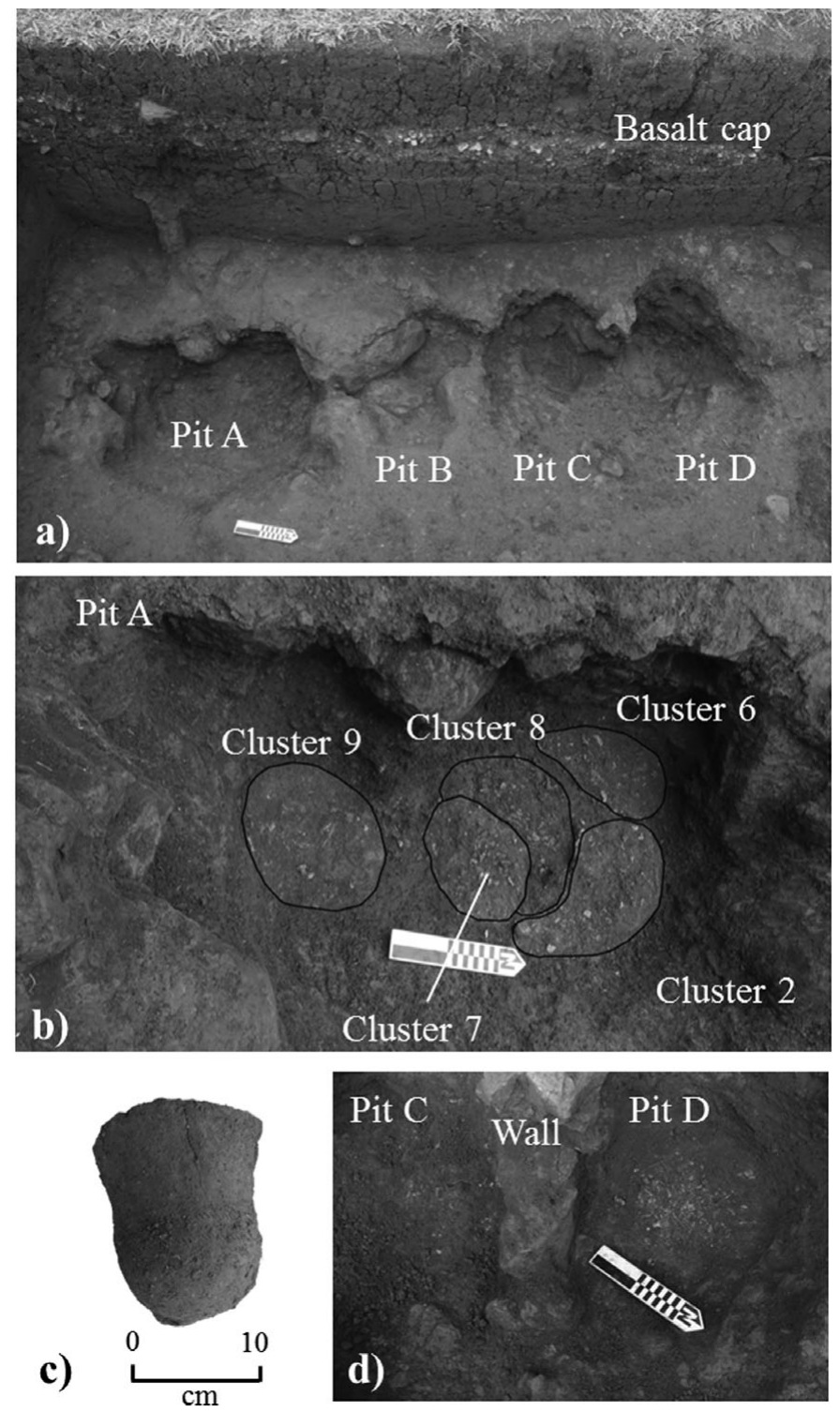

Figure 6. Pits and features in the southwestern half of Mound A: a) the four bedrock cut pits and the basalt cap, b) location of cremation deposits in Pit A, c) ceramic cup from Pit A, d) the constructed wall separating Pits $\mathrm{C}$ and $\mathrm{D}$.

as one), the mound excavation contained only 18 ceramics: seven sherds from the northeastern side (density $=0.78 / \mathrm{m}^{3}$ ) and nine from the southwestern half $\left(\right.$ density $=1.22 / \mathrm{m}^{3}$ ). Nine of these sherds were recovered from above the basalt cap, nine from below.

\section{Mound B}

Mound B was also constructed in two phases, with a basalt cap defining the first phase. A
$2 \times 1 \mathrm{~m}$ excavation was opened across the center of the mound. A well-defined, circular concentration of cremated bone and charcoal (360 \pm 30 B.P.) sat within a small depression cut into the underlying basalt bedrock in the west of the excavation. Seven ceramic sherds were recovered from the mound fill (density $=5.83 / \mathrm{m}^{3}$ ). The contemporary date of a second, less-defined deposit in the northwest ( $330 \pm 20$ B.P.) confirms the concurrent use of Mound A and Mound B. 


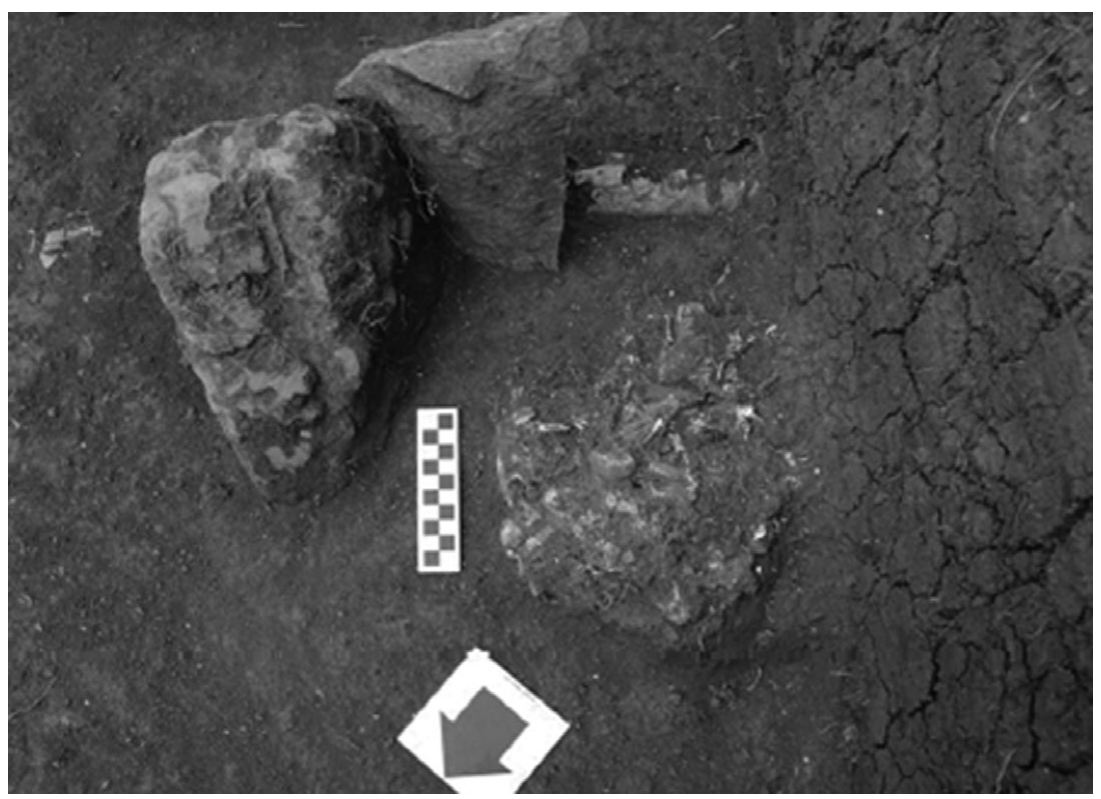

Figure 7. Cluster 1 with associated grave architecture.

\section{MEC1-Enclosure Rim}

A $1 \times 10 \mathrm{~m}$ trench excavation was undertaken across the outer rim with the aim of understanding form and construction history. The continuous circular rim showed a single construction phase, unlike the mounds. A total of 13 ceramic sherds were found between 10 and $40 \mathrm{~cm}$ depth, located in the bank or immediately on the outer side. The excavated area between the mounds and the rim was devoid of artifacts. This positioning suggests that at least some of the material represents the remains of activities performed atop the mound and discarded off the back, perhaps with deliberate clearance of the inner enclosure. A separate $4 \times 1 \mathrm{~m}$ trench inside the MEC1 enclosure recovered zero artifacts, further suggesting that the internal enclosure was kept clean of debris.

\section{$M E C 2$}

Mound C of the smaller MEC2 revealed a single construction phase. A $2 \times 2 \mathrm{~m}$ unit was established over the center of the mound, with an $8 \times 1 \mathrm{~m}$ trench extending off the northwest side, across the interior of the enclosure, through the encircling ditch and terrace toward MEC1. A low-density scattering of bone fragments was present in the eastern corner of the excavation between 20 and $30 \mathrm{~cm}$ below the modern ground surface; nevertheless, no distinct clustering or concentration was present. Two ceramic sherds were present within the mound fill (density $=$ $\left.1.67 / \mathrm{m}^{3}\right)$. Eight ceramic sherds found in the trench within the enclosure (density $=7.92 / \mathrm{m}^{3}$ ) lack distinct contextual information but may be vestiges of activities performed within the enclosure or may have been swept from atop the mound. Although still in small numbers, the presence of material within the enclosure contrasts with MEC1, which was kept perfectly clean.

External Area. A $3 \times 2$ m excavation was established to test the area between MEC1 and MEC2. Thirty $1 \times 1 \mathrm{~m}$ test units (not shown on map) were dug in the southern sector outside of MEC1 to sample a total area of $180 \mathrm{~m}^{2}$. Interestingly, the highest density of ceramic material across the site was encountered within these areas (density $=$ $10.83 / \mathrm{m}^{3}$ ). The quantity of ceramics is distinct from the limited material in the internal area of MEC1 and hints at less-controlled activity outside of the enclosure. No other material or features were recorded.

\section{Summary}

Excavations at Abreu Garcia confirm that both MECs and all mounds were mortuary in nature, 
although they are distinct in terms of form, interments, and associated activities. Mound A of MEC1 is particularly interesting, revealing two construction phases and a history of reentry, with the interment of 16 cremation deposits. Most startling is the distinct difference between the two sides of the mound interior, aligned to the plateau's edge, adding yet another level of dualism to the paired MECs and twin mounds of MEC1.

\section{Discussion}

In the discussion that follows we draw parallels between the archaeology of the southern protoJê and the sociopolitical organization of the southern Jê Kaingang groups. The comparison serves as a point of departure to explore the historical continuity of general underlying ideological and structural arrangements that have survived over time. Nonetheless, we are aware of the pitfalls associated with direct transposition of the ethnographic present into the archaeological record. From here on we refer to Alpha and Beta moieties, rather than the Kamé and Kairu moieties, to facilitate discussion and avoid implying direct association through the use of Kaingang terminology. Alpha represents the more dominant moiety.

\section{Dualism in Site Plan}

Iriarte et al. (2013) argue for a pattern of dual social organization in the southern proto-Jê funerary landscape, noting the common occurrence of paired MECs. Paired complexes are asymmetric, with the larger complex almost always occupying a slightly higher topographic position, typically to the southwest, in a southwest-northeast alignment. These characteristics correlate with the associations attached to the dominant Kamé moiety of the Kaingang (Crépeau 1994, 2002, 2005; Iriarte et al. 2013; Silva 2002; Veiga 1994, 2000).

The southwest-northeast arrangement is particularly apparent in Pinhal da Serra, where five of the six paired structures follow the pattern (Iriarte et al. 2013). The main structure of site PM-01 in Misiones also contained two mounds with marked disparities in size, the larger of which was located to the west (Iriarte et al.
2008). The architectural placement corresponds to the shadow alignment of sunrise during the winter solstice and sunset during the summer solstice, which could represent an early reference to the Sun and Moon as embodied by Kamé and Kairu in Kaingang. It is perhaps of significance that a nineteenth-century account mentions that the shadow of an upright arrow was used by the Kaingang to align the body of the deceased (Mabilde 1983).

Deviations from the southwest-northeast pattern can be explained by other landscape features, such as plateau orientation and topography superseding the directional layout. The distinct plateau of Abreu Garcia is one such deviation, with the Alpha MEC (MEC1) occupying a higher position to the northeast and both MEC and the pithouse parallel to the edge of the plateau, suggesting that viewshed and landscape symmetry were more important criteria than directional layout. It is important to note that the opposition between high and low places is more important in modern Kaingang cemeteries than the eastwest division (Crépeau 1994, 2002). SC-CL94 (Schmitz et al. 2010), another paired MEC over $50 \mathrm{~km}$ from Pinhal da Serra, also deviates from the southwest-northeast pattern, raising the possibility that the feature may be a localized tradition in the Pinhal da Serra region.

Whether the paired structures were reserved for, or controlled by, the relevant moiety, or if the structures were a representation of cosmological structure and used by the whole community, is difficult to discern with the limited excavated samples. In a paired complex at SC-AG-12, De Masi $(2005,2006,2009)$ documented the cremated burial of an adult and an infant, accompanied by a well-preserved, complete ceramic plate and cup in the central mound of the larger enclosure. Six collective cremated burials were recovered in the smaller MEC. Based on this evidence, De Masi (2009) posited that the two individuals in the larger enclosure had a higher status than the multiple burials in the smaller enclosure, with the funerary landscape reflecting societal divisions. At Abreu Garcia, MEC2 contrasts with MEC1 in terms of form, interments, and artifact distribution. The smaller and topographically lower MEC2 contains only a scattering of bone in the mound but a higher 

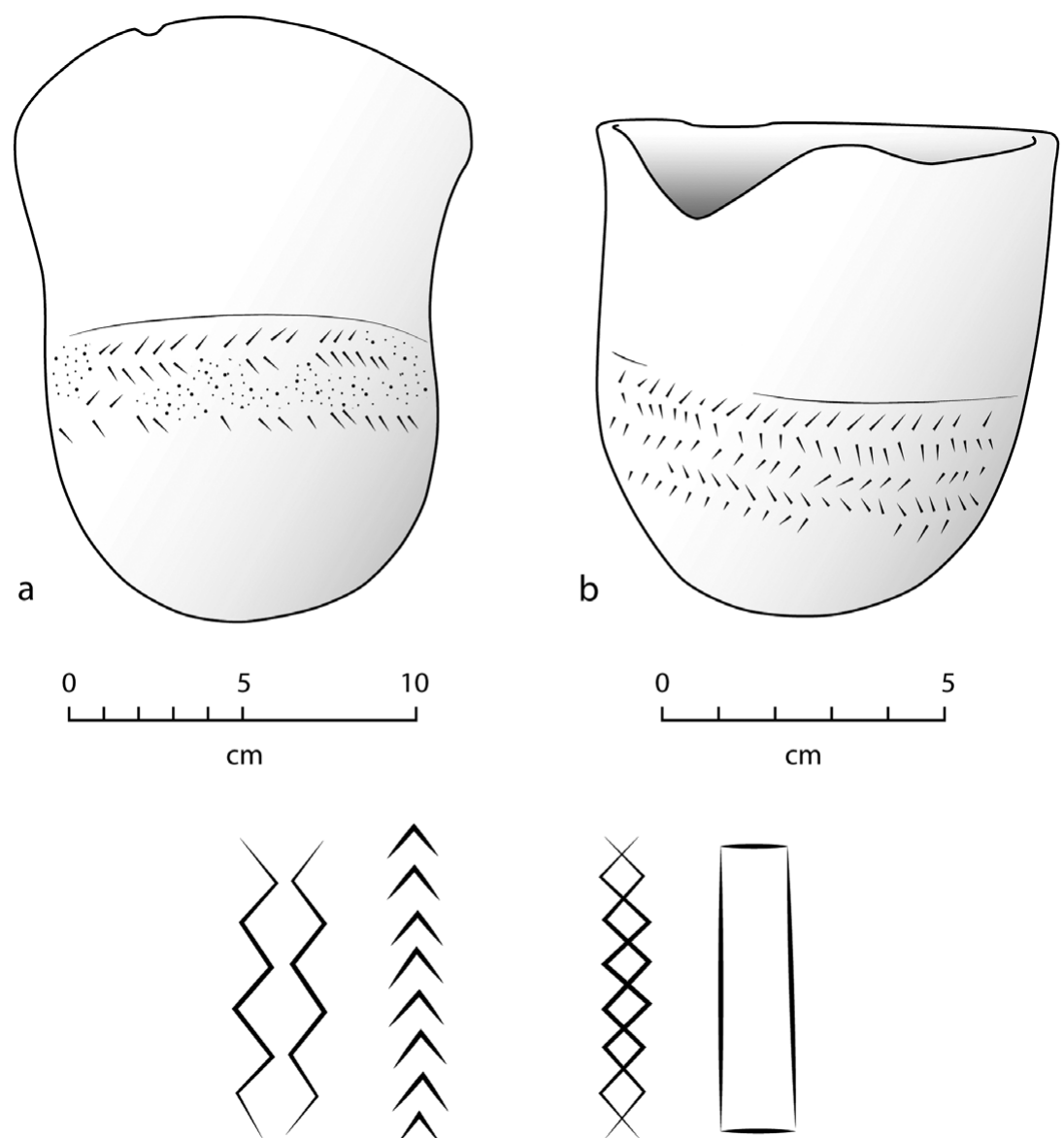

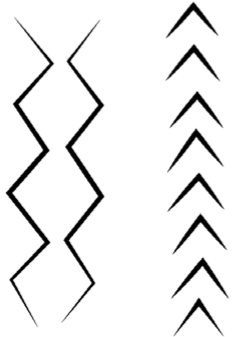

C

d

Figure 8. Decorated ceramics from a) Pit $A$ in Mound $A$ at Abreu Garcia, and b) SC-AG-12. c) Represents typical open designs used in body painting and associated with the Kamé moiety, and d) represents the closed designs used by the Kairu moiety.

density of ceramics within the enclosure, suggesting differences in ritual practice, at least. The difference between the enclosing ditch of MEC2 and the ring of MEC1 is another disparity and may reflect moiety-specific architectural styles.

Dualism in Materials. Although a greater density of ceramic material was recovered from MEC2 than MEC1, the only distinctly interred offerings were the vessels recovered from the southwestern half of MEC1. These vessels are strikingly similar in form to the ceramic cups retrieved from other MECs (De Masi 2005; Müller 2008; Rohr 1971; Saldanha 2005). The band of zigzag decoration on the cup from Pit A is comparable, in particular, to the ceramic cup from the mound of the larger enclosure at SCAG-12 (De Masi 2009; Figure 8). Here again, it is enlightening to compare the archaeological data with the ethnographic record. Among the historical Kaingang, the same design style was used in the body painting of the Kamé moiety (Da Silva 2001), and the equivalent Xokleng clan used similar linear decorations (Métraux 1946). These designs were in opposition to the dots and circles worn by the other Kaingang moiety and Xokleng clan.

Modern southern Jê mortuary practice emphasizes the personal attachments of the deceased within strictly structured ritual underscored by 
the moiety system. Possessions of the deceased are broken and included in the burial; pets may even be sacrificed so that the dead do not return, seeking what is theirs (Veiga 2000). This last point is particularly pertinent considering the presence of animal bones mixed with human in at least some of the cremation deposits as observed in the field.

\section{Dualism in Internal Mound Space}

Perhaps the most intriguing feature at Abreu Garcia is the distinct disparity between the northeastern and southwestern halves of Mound A. The division is epitomized by the absence of cremated deposits along the centerline of the mound and the stark contrast between the formal bedrock cut pits of the southwestern half and the dispersed interments in the northeast. As well as a distinction made by the formality of the bedrock pits, a vertical spatial division between the two halves is further emphasized by Cluster 1 in the southwestern half being the only deposit positioned above the basalt cap.

The spatial division (and the alignment of the bedrock pits) parallels the alignment of the three structures at Abreu Garcia, which in turn parallels the edge of the plateau. Although there have been relatively few excavations elsewhere in the southern Brazilian highlands, we know that the split into a southwest and a northeast half is analogous to the arrangement of other paired MECs, with the more extravagant offerings and the more formal interments in the western portion, equating to the Alpha moiety (De Masi 2009). Likewise, the smaller mound (Mound B) of MEC1 does not contain any central interments, with the two cremation deposits both located in the western half of the mound.

The whole complex at Abreu Garcia may thus represent three levels of integrated dual organization, manifesting in (1) the paired MEC, (2) the twin mounds within MEC1, and (3) the internal division of the mounds. The multiple levels of dualism are both overt and subtle, perhaps symbolizing the cohesive and mutually dependent nature of the moiety system. Alternatively, the apparent dualism may reflect subdivisions within moieties, enmeshing multiple levels of hierarchy and social division within spatial aspects of mortuary practice.

\section{Grave Architecture}

Architecture is limited to three stone associations and the bedrock pits. The four pits dug into bedrock in the southwestern half of Mound A clearly show a distinct pattern in comparison to the other interments, requiring the concerted decision to excavate into the hard basalt rather than stop and place the burial atop it as in the case of Cluster 16. This marked distinction, located in the west, correlates with the associations of the Alpha moiety.

The stone additions to Clusters 1, 10, and 12 take different forms. The stone slabs of Cluster 1 contrast with the single rectangular cap of the well-defined Cluster 12 and the loose pebble accumulation associated with the spread of Cluster 10. In these three cases the type of stone association mimics the dispersal of the cremation deposit, whereby the more tightly clustered cremation deposits have a clear and direct stone association, and the loosely clustered cremation deposit is associated with a loose concentration of stones, although there are not enough examples to confirm a pattern. Stone architecture accompanying mound interments has been documented elsewhere, including both large slabs (Borba 1908) and smaller rock concentrations (Müller 2008). The reasoning behind the presence or absence of architecture in these cases is also ambiguous. The more formal architecture of all the interments of the southwestern half does offer further support for the interpretation that this side and the more elaborate burial rites were reserved for the Alpha moiety.

\section{Hierarchy}

Ethnographic accounts of Kaingang funerary mounds indicate that the burial of chiefs and the accompanying ceremonies passed chiefly office to their successors; interment of other high-status individuals and actors with specific social roles is also noted (Da Silva 2001; Maniser 1930; Métraux 1946; Veiga 2006). Larger Xokleng mounds were also reserved for highstatus individuals (Vasconcellos 1912). Among the Kaingang, only the death of a paramount chief required the construction of a new mound (Mabilde 1983). Interestingly, collective burial in mounds for warriors who died in battle was 
reported in the nineteenth century (Mabilde 1983). These mounds were built side by side, with individual mounds reserved for deceased chiefs.

MECs certainly did not accommodate the remains of the whole community, and the prestige associated with commanding ceremonies at a prominent public landmark such as Abreu Garcia was likely reserved for higher-status individuals or those associated with specific social functions. Although multiple individuals are sometimes present within a single cremation deposit, the core of each deposit appears to have been conspicuously separate. This is made apparent by the distinctly different material of each deposit in Pit $\mathrm{A}$ and the reconstruction of the wall separating Pit $\mathrm{C}$ and Pit D. While the treatment of each context as a distinct entity is perhaps not surprising, it does reveal conceptualizations of the sacred and profane and indicates an inherent respect for the remains of the deceased.

The dual organization existent among many lowland South American societies has been hypothesized to favor the development of inequality, with the moieties becoming asymmetrical over time (Spencer and Redmond 2015). In fact, as the classical work of Lévi-Strauss (1963) first pointed out, dualistic ideologies usually mask a subjacent asymmetrical structure. This is manifest in the Kaingang moiety system: Kamé burial grounds are placed in higher positions, and they are considered ritually "stronger" (Crépeau 1994, 2002).

Bone Removal. The absence of dentition in all but two contexts at the complex suggests a practice of selective bone collection from the pyre, with some material either separated for use or curation elsewhere or abandoned at the pyre site. No pyre location has been discovered to date, making it impossible to assess whether teeth were left at the cremation site; nor has skeletal material been encountered in other contexts, which would confirm a separate caching practice. Archaeological and ethnographic data regarding practices of bone removal for the southern Jê are scant. Borba's (1908) ethnographic account notes the removal of the cranium for burial within cemeteries or mounds in Paraná. De
Masi's (2005) archaeological analysis indicates that teeth were present for the two cremated individuals in a mound at SC-AG-12, dated to the fifteenth century. Teeth were also reported by Müller (2008) for a cremated burial at SC-AG108. Cranial fragments, including mandible and maxilla fragments, were present in the deposits at Abreu Garcia, confirming that crania were not removed. Teeth will often pop out during the cremation fire, and the small size of the individual teeth may explain why some were not collected with the rest of the bone; nevertheless, the durability of teeth and their distinctiveness would suggest that their absence was a behavioral choice.

The lack of detail regarding elements of skeletal recovery such as teeth at other sites prevents substantive discussion at this time, although the absence of teeth in 14 of 16 interments in Mound A may represent a localized tradition. Perhaps of relevance, Henry (1964) explicitly notes the bad dentition of the modern southern Jê he studied, further recording that in their mythology many malevolent supernaturals were explicitly characterized with good teeth as a sign of their corrupt power. Whether the removal of teeth from the burial contexts is an early concept of profanity associated with dentition has yet to be determined. Ongoing osteological analysis is assessing whether certain bones, or types of bone, were preferentially collected or avoided, and whether any pattern correlated with social organization exists.

\section{Variability in Cremation Deposits}

Despite the spatial division within the mound, a degree of variability in the characteristics of the cremated deposits precludes the identification of further mortuary rites specific to moiety attachment or social role. Variation in grave architecture, number of individuals, presence of faunal bones, and absence of specific bones lacks distinct spatial patterning. Although the location of the interment within the mound and, to a certain extent, the degree of formality in the burial may be indicative of the Alpha and Beta moieties, the variability and overlap in the characteristics of the individual cremation deposits appear to reveal either (1) a nonstandardized 
cremation practice that does not represent community structure; (2) rites that were in flux, lacking codification for an extended period; or (3) personal associations that supplant generalized social categories, with the deceased's more nuanced identity reflected in mortuary rites. A combination of these factors is perhaps most likely, with certain aspects of mortuary ritual considered mandatory and other aspects being optional or non-codified.

Chronology. Chronological change in ritual over the 170-year span of radiocarbon dates from Mound A (Table 1) may account for some of the variability among cremation deposits. The chronological relationships among the bedrock pits are particularly interesting. The postdepositional stratigraphic relationship of the container collapse in Pit A confirms that the remains were deposited in a single event within the sealed pit, but did the individuals die at the same time? Were they cremated at the same time (albeit in different pyres)? Or were they curated until the burial event? Despite the similarities among the four pits, the stratigraphic relationship between Pit C, Pit D, and the constructed wall implies a chronological separation between the two interment events. More refined dating may help tease out the relationships among the cremated deposits, although the error ranges in radiometric dating, old wood issues, and problems with dating cremated bone could easily obscure and conflate separate interment events over the relatively short span of occupation.

\section{Summary and Conclusions}

Abreu Garcia provides a detailed case study of a mound and enclosure mortuary complex used by the southern proto-Jê. The discovery of 16 cremation deposits within Mound A allows an in-depth discussion of mortuary practice within a single monument. MEC1 was built in two phases. The initial construction included the enclosure rim and the two basalt-capped mounds. After the second construction phase, multiple reentries that deposited cremations continued the active use of the mound. Throughout its history, a distinct separation between two halves of the mound was respected-a division that paralleled the direction of the edge of the plateau. The smaller mound of MEC1, Mound B, lacked any central deposits, potentially also following a dual separation. Contrasting practices at the singlephase MEC2 may be a monumental reflection of the asymmetric dual social structure.

Although there is a distinct difference in the formality of the cremation deposits between the northeastern and southwestern halves of Mound A, with the bedrock cut pits in the southwest in stark contrast to the deposits of the northeast, there is a level of variability among the cremation deposits that lacks distinct patterning. Cremation deposits across the complex show variability in the presence of grave architecture, faunal remains, number of individuals, and postcremation treatment. A lack of patterning and replication of the interment characteristics precludes the identification of funerary rites attached to distinct social identities. The absence of standardized practice among the cremation deposits is made more acute when contrasted with the high level of structured spatial division both on the landscape and in the internal mound division. Mortuary rites may therefore reflect a combination of nonstandardized and mandated practices, with certain ceremonies and elements deemed essential and other rites considered optional or in flux as the codified norms of funerary ritual develop and evolve.

The Abreu Garcia complex provides another southern proto-Jê example of site planning revolving around spatial alignments as well as the use of distinct size differences in structures within paired arrangements. Excavation at the site adds another level of dualism to the mortuary landscape, however, extending spatial organization into the interior of Mound A. The presence of paired MECs on the plateau, paired mounds within MEC1, and a spatial division within Mound A reveals multiple levels of nested dualism. The nested nature of the dualism highlights both the opposition and the complementarity of the moiety system. Exactly how the complex was used by the moieties and by society as a whole remains ambiguous, but the incorporation of asymmetry at three nested levels demonstrates the necessity for both moieties to be represented as part of a complementary whole, just as the Kaingang kiki ritual requires the participation of 
both moieties while also maintaining spatial and practical divisions.

The findings at Abreu Garcia offer new insights into fundamental aspects of southern proto-Jê social organization, including the dual nature of the community, the manifestation of social structure on the landscape, and the incorporation of duality into mortuary ritual. The identification of multiple levels of dualism, down to an internal mound division, raises important considerations for the excavation and interpretation of archaeological contexts. The findings have implications for research design and the development of appropriate methodologies to answer culture-specific questions. Future research can be designed through an emic lens, testing for dualism within archaeological contexts. Furthermore, the parallels among the archaeological record, ethnohistorical accounts, and ethnographic examples enable an understanding of the foundation of modern descendent groups and an assessment of the continuity in indigenous culture beyond European contact.

Acknowledgments. Research is funded by an AHRCFAPESP grant for the project "Je Landscapes of Southern Brazil: Ecology, History, and Power in a Transitional Landscape during the Late Holocene" (AH/K004212/1), awarded to JI, FM, and PD. JGS, RC, and PU received funding from CAPES, Ministry of Education, Brazil. We are grateful to the Garcia family and all the field crew involved in the excavation. Research was conducted under permit 01510.000426/201480(2014-2016) from the Instituto do Patrimônio Histórico e Artístico Nacional (IPHAN).

Data Availability Statement. All paper and digital files are curated in the Department of Archaeology, University of Exeter, Devon, UK. All physical material from the excavation is curated at the University of South Santa Catarina (UNISUL), Tubaráo, Santa Catarina State, Brazil. Access to all material can be arranged via contact with José Iriarte (j.iriarte@exeter.ac.uk).

\section{References Cited}

Araújo, Astolfo

2007 A tradição cerâmica Itararé-Taquara: Características, área de ocorrência e algumas hipóteses sobrea expansão dos grupos Jê no sudeste do Brasil. Revista Arqueologia 20:9-38.

Baldus, Herbert

1937 Ensaios de ethnologia brasileira. Companhia Editorial Nacional, São Paulo.

Beber, Marcus V.

2005 O sistema do asentamento dos grupos ceramistas do planalto sul brasilero: $\mathrm{O}$ caso da tradição
Taquara/Itarare. Documentos (Instituto Anchietano de Pesquisas, São Leopoldo) 10:5-125.

Becker, Ítala I.

1976 O indio Kaingang no Rio Grande do Sul. Universidade do Vale do Rio dos Sinos, São Leopoldo.

Behling, Hermann

1995 Investigations into the Late Pleistocene and Holocene History of Vegetation and Climate in Santa Catarina (S Brazil). Vegetation History and Archaeobotany 4(3):127-152.

1998 Late Quaternary Vegetational and Climatic Changes in Brazil. Review of Palaeobotany and Palynology 99(2):143-156.

Binford, Lewis R.

1971 Mortuary Practices: Their Study and Their Potential. Memoirs of the Society for American Archaeology 25:6-29.

Bitencourt, Ana L. V., and Patrícia M. Kraspenhar

2006 Possible Prehistoric Anthropogenic Effect on Araucaria angustifolia (Bert.) O. Kuntze Expansion during the Late Holocene. Revista Brasileira de Paleontologia 9:109-116.

Borba, Telêmaco

1908 Actualidade indigena: Paraná-Brazil. Impressora Paranaense, Curitiba.

Bronk Ramsey, Christopher

2009 Bayesian Analysis of Radiocarbon Dates. Radiocarbon 51(1):337-360.

Chmyz, Igor

1968 Subsídios para o estudo arqueológico do Vale do Rio Iguacu. Revista do Centro Ensino e Pesquisas Arqueologicas 1:31-52.

Copé, Silvia M.

2006 Les grands constructeurs précoloniaux du sud Brésil: Etude de paysages archéologiques a Bom Jesus, Rio Grande do Sul, Brésil. Paris I Panthéon-Sorbonne, Paris.

Copé, Silvia M., and Joao D. Saldanha

2002 Em busca de um sistema de assentamento para o plan alto Sul-Rio-Grandense: Escavações no sítio RS-AN03, Bom Jesus, RS. Pesquisas Antropologia 58:107120.

Copé, Silvia M., Joao D. Saldanha, and Petry Cabral

2002 Contribuições para a pré-história do planalto: Estudo da variabilidade de sítios arqueológicos de Pinhal da Serra, RS. Pesquisas Antropologia 58:121-138.

Corteletti, Rafael

2012 Projeto arqueológico Alto Canoas-Paraca: Um estudo da presença Jê no planalto catarinense. Universidade de Sao Paulo, Sao Paulo.

Corteletti, Rafael, Ruth Dickau, Paulo De Blasis, and José Iriarte

2015 Revisiting the Economy and Mobility of Southern Proto-Jê (Taquara-Itararé) Groups in the Southern Brazilian Highlands: Starch Grain and Phytoliths Analyses from the Bonin Site, Urubici, Brazil. Journal of Archaeological Science 58:46-61.

Crépeau, Robert R.

1994 Mythe et rituel chez les indiens Kaingang du Bresil meridional. Religiologiques 10:143-157.

2002 A prática do xamanismo entre os Kaingang do Brasil meridional: Uma breve comparação com o xamanismo Bororo. Horizontes Antropológicos 8:113-129.

2005 Os Kamé vão sempre primeiro: Dualismo social e reciprocidade entre os Kaingang. Anuário Antropológico 2005:9-33. 
Cruz Conceiçáo, Lays

2015 Vivências de escritas entre os Laklãnõ/Xokleng. Master's thesis, Departamento de Antropologia, Universidade Federal de Santa Catarina, Florianópolis.

Da Silva, Lucas A.

2011 A história Kaingáng a través do ritual do Kiki. Revista Santa Catarina em História 5(1):11-23.

Davis, Irvine

1966 Comparative Jê Phonology. Estudos Linguísticos: Revista Brasileira de Linguística Teórica e Aplicada 2:10-24.

1968 Some Macro-Jê Relationships. International Journal of American Linguistics 34:42-47.

De Masi, Marco A.

2005 Projeto de salvamento arqueológico usina hidrelétrica de Campos Novos. Relatorio Final, Florianópolis.

2006 Xokleng 2860 a.c. as terras altas do sul do Brasil. Editora Unisul, Tubarão.

2009 Centros ceremoniais do plan alto meridional: Uma análise intrasítio. Revista de Arqueologia SAB 22:99113

De Souza, Jonas G., and Silvia M. Copé

2010 Novas perspectivas sobrea arquitetura ritual do plan alto meridional brasileiro: Pesquisas recentes em Pinhal da Serra, RS. Revista Arqueologia 23:98111.

De Souza, Jonas G., Rafael Corteletti, Mark Robinson, and José Iriarte

2016 The Genesis of Monuments: Resisting Outsiders in the Contested Landscapes of Southern Brazil. Journal of Anthropological Archaeology 41:196-212.

Dillehay, Tom D.

1995 Tombs for the Living: Andean Mortuary Practices. Dumbarton Oaks Research Library and Collection, Washington, DC.

Henry, Jules

1964 Jungle People: A Kaingáng Tribe of the Highlands of Brazil. Vintage Books, New York.

Herberts, Ana L., and Letícia M. Müller

2007 Os sítios funerários do projeto de arqueologia compensatória UHE Barra Grande. Anais do XIV Congresso da SAB. CD-ROM.

Hoffman, Kaio D.

2010 De alguns pressupostos analíticos na literatura sobre os Xokleng: Esboço para uma breve revisão bibliográfica. Espaço Ameríndio 4(2): 233.

Hogg, Alan G., Quan Hua, Paul G. Blackwell, Mu Niu, Caitlin E. Buck, Thomas P. Guilderson, Timothy J. Heaton, Jonathan G. Palmer, Paula J. Reimer, Ron W. Reimer, Christian S. M. Turney, and Susan R. H. Zimmerman.

2013 SHCal13 Southern Hemisphere Calibration, 050,000 Years Cal BP. Radiocarbon 55(2):1-15.

Hornborg, Alf

1988 Dualism and Hierarchy in Lowland South America: Trajectories of Indigenous Social Organization. Almquist and Wiksell International, Stockholm.

Iriarte, José, and Hermann Behling

2007 The Expansion of Araucaria Forest in the Southern Brazilian Highlands during the Last 4000 Years and its Implications for the Development of the Taquara/ Itararé Tradition. Environmental Archaeology 12:115127.

Iriarte, José, Silvia M. Copé, Michael Fradley, Jami J. Lockhart, and J. Christopher Gillam
2013 Sacred Landscapes of the Southern Brazilian Highlands: Understanding Southern Proto-Jê Mound and Enclosure Complexes. Journal of Anthropological Archaeology 32:74-96.

Iriarte, José, Paulo DeBlasis, Jonas G. Souza, and Rafael Corteletti

2016 Emergent Complexity, Changing Landscapes and Spheres of Interaction in South-Eastern South America during the Mid and Late Holocene. Journal of Archaeological Research. DOI:10.1007/s10814-016-9100-0, accessed May 16, 2017.

Iriarte, José, J. Christopher Gillam, and Oscar Marozzi

2008 Monumental Burials and Memorial Feasting: An Example from the Southern Brazilian Highlands. Antiquity 82:947-961.

Iriarte, José, Oscar Marozzi, and J. Christopher Gillam

2010 Monumentos funerarios y festejos rituales: Complejos de recintos y túmulos Taquara/Itarare en El Dorado, Misiones (Argentina). Revista de Arqueología Iberoamericana 6:25-38.

Jolkesky, Marcelo

2010 Reconstrução fonológica e lexical do proto-Jê meridional. Master's thesis, Instituto de Estudos da Linguagem, Universidade Estadual de Campinas, Campinas.

Klein, Roberto M

1975 Southern Brazilian Phytogeographic Features and the Probable Influence of Upper Quaternary Climatic Changes in the Floristic Distribution. Boletim Paranaense de Geociências 33:67-88.

Lévi-Strauss, Claude

1944 On Dual Organization in South America. America Indigena 4(1):37-47.

1963 Do Dual Organizations Exist? Structural Anthropology 1:1951-1982.

Loch, Silvia

2004 Arquitecturas Xoklengs contemporâneas: Uma introdução á antropologia do espaçona terra indígena de Ibirama. Master's thesis, Departamento de Antropologia, Universidade Federal de Santa Catarina, Florianópolis.

Mabilde, Pierre F.

1983 Apontamentos sobreos indígenas selvagens da nação coroados dos matos da Província do Rio Grande do Sul. IBRASA/INL/Fundação Nacional PróMemória, São Paulo/Brasília.

Maniser, Henry $\mathrm{H}$.

1930 Les Kaingang de São Paulo. In Proceedings of the 23rd International Congress of Americanists, pp. 760 791. Science Press, New York.

Martius, Karl F. P. von

1867 Beiträge zur Ethnographie und Sprachenkunde Amerikas zumal Brasiliens. 2 vols. Friedrich Fleischer, Leipzig.

Maybury-Lewis, David

1979 Dialectical Societies: The Gê and Bororo of Central Brazil. Harvard University Press, Cambridge, Massachusetts.

Métraux, Alfred

1946 The Caingang. In Handbook of South American Indians, edited by Julian H. Steward, pp. 445-477. Smithsonian Institution, Washington, DC.

Moore, Jerry D.

1995 The Archaeology of Dual Organization in Andean South America: A Theoretical Review and Case Study. Latin American Antiquity 6:165-181. 
Müller, Letícia M.

2008 Sobre indios e ossos: Estudo de três sítios de estruturas anelares construídos para enterramento por populações que habitavam o vale do Rio Pelotas no período pré-contato. Master's thesis, Departamento de Historia, Pontificia Universidad Catolica do Rio Grande do Sul, Porto Alegre.

Müller, Letícia M., and Sheila Mendonça de Souza

2011 Cremações e sepultamentos: As estruturas anelares do planalto. In Antes do oeste catarinense: Arqueologia dos povos indígenas, edited by Mirian Carbonera and Pedro I. Schmitz, pp. 269-305. Pontifical Catholic University of Rio Grande do Sul, Chapecó.

Naue, Guilherme, José J. P. Brochado, Fernando La Salvia, and José O. C. Souza

1989 Projeto campos novos: Relatorio. Pontifical Catholic University of Rio Grande do Sul, Porto Alegre.

Nimuendajú, Curt

1993 [1913] Nota sobre a festa do Kikio-ko-ia dos Kaingang. In Etnografia e indigenismo sobre os Kaingang, os Ofaié-Xavante e os indios do Pará, edited by Curt Nimuendajú, pp. 67-69. Editorial da Unicamp, Campinas.

Nimuendajú, Curt, and Robert H. Lowie

1937 The Dual Organizations of the Ramko'kamekra (Canella) of Northern Brazil. American Anthropologist 39(4):565-582.

Noelli, Francisco $\mathrm{S}$

2000 A ocupação humana na região sul do Brasil: Arqueologia, debates e perspectivas 1872-2000. Revista USP 44:218-269.

2005 Rethinking Stereotypes and the History of Research on Jê Populations in South Brazil: An Interdisciplinary Point of View. In Global Archaeological Theory: Contextual Voices and Contemporary Thoughts, edited by Pedro P. Funari, Andrés Zarankin, and Emily Stovel, pp. 167-190. Springer, New York.

O'Shea, John

1984 Mortuary Variability: An Archaeological Investigation. Academic Press, New York.

Paula, José M.

1924 Memória sobre os botocudos de Paraná e Santa Catarina organisada pelo Serviço de Proteçãoa os Selvícolas sob a inspeccão. In Anais do 200 Congresso Internacional de Americanistas, edited by Léon Clerot and Paulo Brandão, pp. 117-137. Imprensa Nacional, Rio de Janeiro.

Pearson, Mike P.

1999 The Archaeology of Death and Burial. Phoenix Mill, Sutton.

Reis, Maria José

2007 A problemática arqueológica das estruturas subterrâneas no planalto catarinense. Habilis, Erechim.

Ribeiro, Eduardo R.

2006 Macro-Jê. In Encyclopedia of Language and Linguistics, Vol. 7, edited by Keith Brown, pp. 422-426. 2nd ed. Elsevier, Oxford.

Ribeiro, Pedro A., and Catharina T. Ribeiro

1985 Levantamentos arqueológicos no municipio de Esmeralda, Rio Grande do Sul, Brasil. Revista do CEPA 14:49-105.

Riris, Philip, and Rafael Corteletti

2015 A New Record of Pre-Columbian Engravings in Urubici (SC), Brazil Using Polynomial Texture Mapping. Internet Archaeology 38. DOI:https://doi.org/10. 11141/ia.38.7, accessed May 16, 2017.
Rodrigues, Aryon D.

1999 Macro-Jê. In The Amazonian Languages, edited by Robert M. W. Dixon and Alexandra Aikhenvald, pp. 164-206. Cambridge University Press, Cambridge.

Rohr, J. Alfredo

1971 Os sítios arqueológicos do plan alto catarinense. Pesquisas Antropologia 24:1-56.

Saldanha, João D. M

2005 Paisagem, lugares e cultura material: Uma arqueologia espacial nas terras altas do sul do Brasil. Master's thesis, Pontifícia Universidade Católica do Rio Grande do Sul, Porto Alegre.

Santos, Silvio Coelho dos

1973 Indios e brancos no sul do Brasil a dramatica expenência dos Xokleng. Movimento, Porto Alegre.

Schmitz, Pedro I., Fúlvio V. Arnt, Marco V. Beber, André Rosa, and Deisi Scunderlik de Farias

2010 Casas subterrâneas no planalto de Santa Catarina: São José do Cerrito. Pesquisas Antropologia 68:7-78.

Schmitz, Pedro I., Jairo H. Rogge, Raul V. Novasco, Natalia M. Mergen, and Suliano Ferrasso

2013 Rincão dos albinos: Um grande sítio Jê meridional. Pesquisas Antropologia 70:65-131.

Silva, Sergio B. D.

2001 Etnoarqueologia dos grafismos Kaingang: Um modelo para a compreensão das sociedades proto-Jê meridionais. Ph.D. dissertation, Facultad de Filosofia, Letras e Ciências Humanas, Universidade de São Paulo, São Paulo.

2002 Dualismo e cosmologia Kaingang: O xamã e o domínio da floresta. Horizontes Antropológicos 8(18):189-209.

Spencer, Charles S., and Elsa M. Redmond

2015 Dual Organization and Social Inequality in a Venezuelan Chiefdom, AD 550-1000. Journal of Anthropological Archaeology 40:135-150.

Tainter, Joseph A.

1978 Mortuary Practices and the Study of Prehistoric Social Systems. Advances in Archaeological Method and Theory 1:105-141.

Tarlow, Sarah, and Liv N. Stutz

2013 The Oxford Handbook of the Archaeology of Death and Burial. Oxford University Press, Oxford.

Turner, Terence

1996 Social Complexity and Recursive Hierarchy in Indigenous South American Societies. Journal of the Steward Anthropological Society 24:37-59.

Urban, Greg

1978 A Model of Shokleng Social Reality. Ph.D. dissertation, Department of Anthropology, University of Chicago, Chicago, Illinois.

1985 Interpretations of Inter-Cultural Contact: The Shokleng and Brazilian National Society 1914-1916. Ethnohistory 32(3):224-244.

1992 A história da cultura brasileira segundo as línguas nativas. In História dos índios no Brasil, edited by Manuela Carneiro da Cunha, pp. 87-102. Companhia das Letras, São Paulo.

Vasconcellos, Diego R.

1912 Botocudos. Revista da Sociedade de Geographiado Rio de Janeiro 17:19-22.

Veiga, Juracilda

1994 Organização social e cosmovisção Kaingang: Uma introdução ao parentesco, casamento e nominação em uma sociedade Je meridional. Unicamp, Campinas. 
2000 A retomada da festa do Kikikoi no P.I. Xapecó e a relação desse ritual com os mitos Kaingang. In Uri e Wãxi: Estudos interdisciplinares dos Kaingang, edited by Lúcio. T. Motta, pp. 261-292. EUL, Londrina.

2006 Aspectos fundamentais da cultura Kaingang. Editora Curt Nimuendajú, Campinas.

Wiik, Flavio B, and Lúcio T. Mota

2014 Apresentando o dossiê: Estudos sobre as sociedades Jê (Kaingang e Xokleng) no sul do Brasilem
Perspectiva. Mediações-Revista de Ciências Sociais 19(2): 10-17.

Zuidema, Reiner T.

1964 The Ceque System of Cuzco: The Social Organization of the Capital of the Inca. Brill Archive, Leiden.

Submitted May 7, 2016; Revised September 22, 2016; Accepted January 13, 2017 